\title{
Type 1 fimbriae in commensal Escherichia coli derived from healthy humans*
}

\author{
Paweł Pusz ${ }^{\bowtie}$, Ewa Bok, Justyna Mazurek, Michał Stosik and Katarzyna Baldy-Chudzik \\ Department of Biological Sciences, University of Zielona Góra, Poland
}

Type 1 fimbriae are one of the most important factors of Escherichia coli adaptation to different niches in the host. Our study indicated that the genetic marker - fimH gene occurred commonly in commensal $E$. coli derived from healthy humans but expression of the type 1 fimbriae was not observed. Identification of fim structural subunit genes (fimA-fimH) and recombinase fimE and fim $B$ genes showed that many of the strains were carrying an incomplete set of genes and the genes expression study revealed that in strains with complete set of fim genes, the fim $C$ gene, encoding the chaperone protein, was not expressed.

Key words: commensal E. coli, type 1 fimbriae, gene expression

Received: 31 October, 2013; revised: 17 March, 2014; accepted: 01 April, 2014; available on-line: 20 May, 2014

\section{INTRODUCTION}

Type 1 fimbriae, the fimbrial adhesins, are important for Escherichia coli adherence to both biotic and abiotic surfaces and are responsible for specific interactions with mannose-containing receptors found in many host tissues. This surface structure plays a role in the infection and colonization process of human body by two mechanisms: adherence and invasion. It is also believed to be an important virulence factor in many extraintestinal infections in humans, especially infections of urinary tract caused by E. coli (Mitra et al., 2013).

The type 1 fimbrial adhesin is encoded by a fim gene cluster (Fig. 1), including nine genes required for its biosynthesis (Iida et al., 2001), the fim $A$ gene encoding the major subunit, fim F and fim $G$ genes encoding two minor subunits and fimH gene coding the mannose-sensitive tip of fimbriae. There are two genes involved in transport and assembly of type 1 fimbriae within the fim gene cluster: fim $C$ and fimD. The fim $C$ gene encodes a chaperone protein that helps to translocate fimbrial proteins through the periplasm and fimD gene encodes an integral outer membrane protein that serves as an usher. Furthermore, fimI gene encodes a structural component (Schwan, 2011). The expression of the fim structural subunit genes (fim $A-f i m H$ genes) is controlled by an invertible promoter region (known as the 'fim switch', fimS). Inversion of the $314 \mathrm{bp}$ switch element is the basis of phase-variable expression of type 1 fimbriae (Blumer et al., 2005) and is catalyzed by two site-specific recombinases encoded by $f \mathrm{mB}$ and $f \mathrm{mE}$ genes located upstream of the fims region. Phase variation yields a heterogenous set of piliated and unpiliated bacteria and may account for differential expression of type 1 fimbriae in different body sites.

The role of the type 1 fimbriae in E. coli in colonization of gastrointestinal tract is still uncertain, therefore here we investigated the presence and expression of fimbrial genes responsible for the active form of type $1 \mathrm{fim}-$ briae in commensal E. coli isolated from healthy humans.

\section{MATERIALS AND METHODS}

Bacterial strains. E. coli strains were isolated from fecal samples derived from 54 healthy adults living in Zielona Góra. Fecal samples were inoculated into agar $\mathrm{m}-\mathrm{FC}$. After $24 \mathrm{~h}$ of incubation at $44.5^{\circ} \mathrm{C}$, blue cultures were passaged onto the MacConkey's agar. Lactopositive strains were subjected to standard biochemical IMVC (indol, methyl-red-voges-proskauer, citrate) tests for E. coli identification. E. coli strains derived from the same person/sample were screened for confirmation of their genomic diversity by the BOX-PCR fingerprinting method (Baldy-Chudzik \& Stosik, 2003). All strains were stored in glycerol broth at $-80^{\circ} \mathrm{C}$ and for subsequent analysis were cultured in Luria-Bertani (LB) media. In total, 127 unique E. coli strains were identified.

Agglutination tests. Mannose-sensitive haemagglutination was determined in phosphate-buffered saline (PBS) with a 5\% suspension of sheep red blood cells sensitized by Tannic Acid, in the presence or absence of 3\% D-mannose (Sigma). Bacterial cultures were grown in LB broth for $16 \mathrm{~h}$ under shaking conditions, then washed in PBS, and suspended to an $\mathrm{OD}_{600} \sim 0.5$. The test was conducted in 96-microwell plates. Twenty-five microliters of the erythrocyte suspension with or without D-mannose was mixed with an equal volume of a bacterial suspension. The haemagglutination reaction was checked after $60 \mathrm{~min}$ and $24 \mathrm{~h}$ under microscope and it was considered to be mannose sensitive when it was inhibited by D-mannose.

Identification of fim genes by PCR. Genes constituting the fim operon were identified by PCR with primers described in Table 1. Representative probes of PCR amplicons for particular genes were sequenced (Genomed) and compared with target sequences in genetic sequence database - GenBank (NCBI).

Restriction analysis of PCR products for identification of the switch position (ON/OFF) in promoter region of the fim operon. The switch position of

e-mail: p.pusz@wnb.uz.zgora.pl

*Presented at the 3-rd Workshop on Microbiology "MIKROBIOT 2013" in Łódź, Poland. 


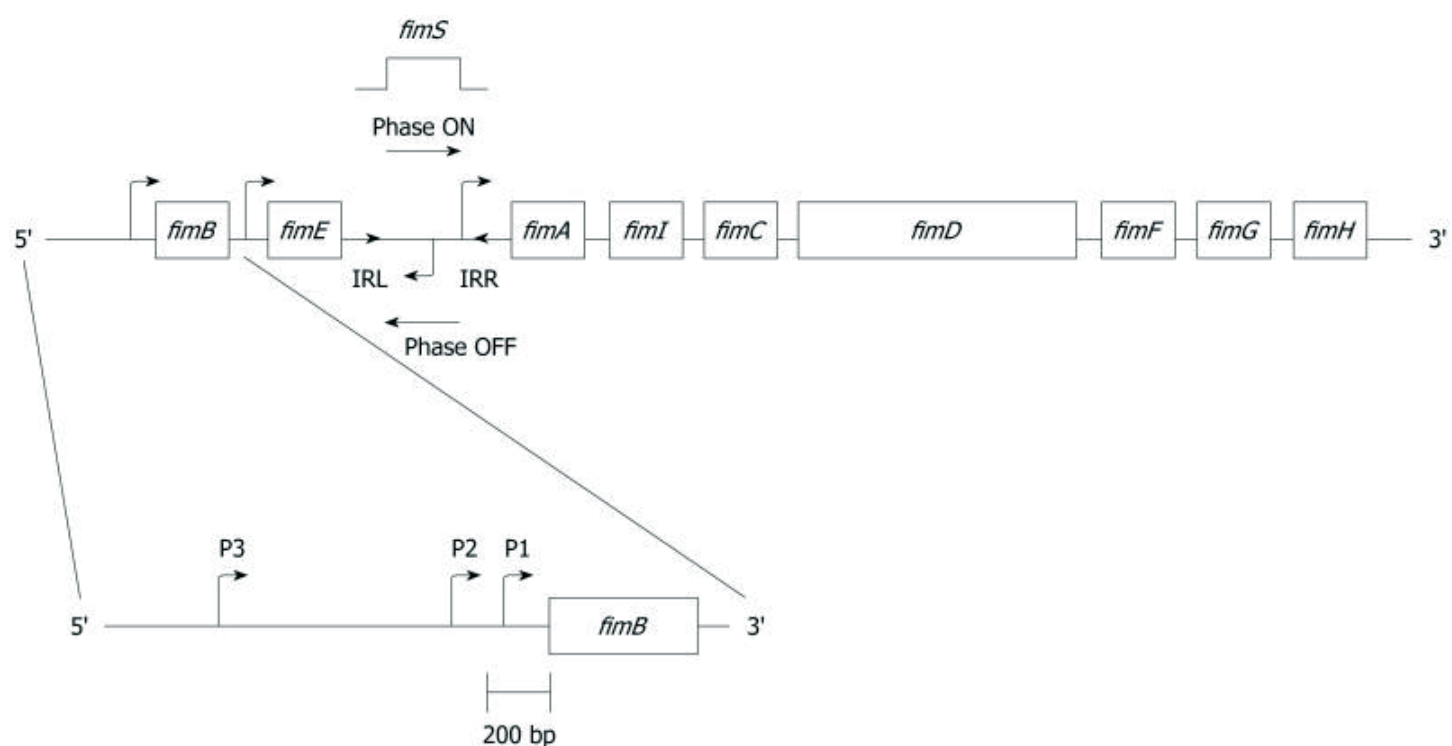

Figure 1. Scheme of the type 1 fimbriae operon (Schwan, 2011).

Table 1. Primers used in this study.

\begin{tabular}{|c|c|c|c|c|c|c|}
\hline Gene & Function & Primer na & es and DNA sequences $\left(5^{\prime}-3^{\prime}\right)$ & References & $\begin{array}{l}\text { Product } \\
\text { size (bp) }\end{array}$ & $\begin{array}{l}\text { GenBank } \\
\text { Accession no. }\end{array}$ \\
\hline \multirow{2}{*}{ fimA } & \multirow{2}{*}{ major subunit } & $\begin{array}{l}\text { FimA-F } \\
\text { FimA-R }\end{array}$ & $\begin{array}{l}\text { AGTTAGGACAGGTTCGTACCGCAT } \\
\text { AAATAACGCGCCTGGAACGGAATG }\end{array}$ & Hernandes et al., 2011 & 315 & KC405511.1 \\
\hline & & $\begin{array}{l}\text { FimA-F* } \\
\text { FimA-R* }\end{array}$ & $\begin{array}{l}\text { GGACAGGTTCGTACCGCATC } \\
\text { ACGTGGTATGACCCGCATC }\end{array}$ & Blumer et al. 2005 & 151 & KC405511.1 \\
\hline \multirow{2}{*}{$f i m B$} & \multirow{2}{*}{ regulator } & $\begin{array}{l}\text { FimB-F } \\
\text { FimB-R }\end{array}$ & $\begin{array}{l}\text { CGAATCACTCCTTAAAGCAG } \\
\text { GGCGTAACATGTGCGGATGAA }\end{array}$ & Schwan et al., 2002 & 379 & EU890414.1 \\
\hline & & $\begin{array}{l}\text { FimB-F* } \\
\text { FimB-R* }\end{array}$ & $\begin{array}{l}\text { ACTGGAGATTCATCCGCACA } \\
\text { GTCGTCCTCTGGCTCTATCC }\end{array}$ & This study & 179 & EU890414.1 \\
\hline \multirow{2}{*}{ fimC } & \multirow{2}{*}{ chaperone } & $\begin{array}{l}\text { FimC-F } \\
\text { FimC-R }\end{array}$ & $\begin{array}{l}\text { GGGTAGAAAATGCCGATGGTG } \\
\text { CGTCATITTGGGGGTAAGTGC }\end{array}$ & Ewers et al., 2007 & 477 & FJ866110.1 \\
\hline & & $\begin{array}{l}\text { FimC-F* } \\
\text { FimC-R* }\end{array}$ & $\begin{array}{l}\text { CTCGCAATTATCAGCCGCAT } \\
\text { GCATTITCAAGAACCCGGGT }\end{array}$ & This study & 182 & FJ866110.1 \\
\hline \multirow{2}{*}{ fimE } & \multirow{2}{*}{ regulator } & $\begin{array}{l}\text { FimE-F } \\
\text { FimE-R }\end{array}$ & $\begin{array}{l}\text { AAACGTCGTTATCTTACCGG } \\
\text { TITCTTTCCCATAATCCGGC }\end{array}$ & Hernandes et al., 2011 & 550 & EU890408.1 \\
\hline & & $\begin{array}{l}\text { FimE-F* } \\
\text { FimE-R* }\end{array}$ & $\begin{array}{l}\text { TATGAATTGGCGGAGCGTGGTG } \\
\text { AAACGAGCAGCATTACTGGCGGTAT }\end{array}$ & Blumer et al. 2005 & 153 & EU890408.1 \\
\hline \multirow{2}{*}{$\mathrm{fimH}$} & \multirow{2}{*}{ adhesin } & $\begin{array}{l}\text { FimH-F } \\
\text { FimH-R }\end{array}$ & $\begin{array}{l}\text { TGCAGAACGGATAAGCCGTGG } \\
\text { GCAGTCACCTGCCCTCCGGTA }\end{array}$ & Chapman et al., 2006 & 508 & FJ865819.1 \\
\hline & & $\begin{array}{l}\text { FimH-F* } \\
\text { FimH-R* }\end{array}$ & $\begin{array}{l}\text { GCTGTGATGTTCTGCTCGT } \\
\text { AAAACGAGGCGGTATTGGTG }\end{array}$ & This study & 168 & FJ865819.1 \\
\hline \multirow{2}{*}{ fiml } & \multirow{2}{*}{ structural protein } & $\begin{array}{l}\text { Fiml-F } \\
\text { Fiml-R }\end{array}$ & $\begin{array}{l}\text { GACGGTCAATATGGGGCAAA } \\
\text { IIIITACCATCCGCGACACC }\end{array}$ & Blumer et al., 2005 & 153 & AF286465.1 \\
\hline & & $\begin{array}{l}\text { Fiml-F* } \\
\text { Fiml-R* }\end{array}$ & $\begin{array}{l}\text { GACGGTCAATATGGGGCAAA } \\
\text { TITITACCATCCGCGACACC }\end{array}$ & Blumer et al. 2005 & 153 & AF286465.1 \\
\hline gapA & $\begin{array}{l}\text { reference gene } \\
\text { for real-time } P C R\end{array}$ & $\begin{array}{l}\text { GapA-F* } \\
\text { GapA-R* }\end{array}$ & $\begin{array}{l}\text { GTTGTCGCTGAAGCAACTGG } \\
\text { AGCGTTGGAAACGATGTCCT }\end{array}$ & Blumer et al. 2005 & 170 & AF424784.1 \\
\hline
\end{tabular}

$\mathrm{F}^{*}$ and $\mathrm{R}^{*}$ - sequences of primers used in real-time PCR 
Table 2. Identification of the fim structural subunit genes and recombinase genes in commensal $E$. coli derived from healthy humans.

\begin{tabular}{|c|c|c|c|c|c|c|}
\hline \multirow{2}{*}{$\begin{array}{l}\text { Number of } \\
\text { E. coli } \\
\mathrm{n}(\%)\end{array}$} & \multicolumn{6}{|c|}{ Genes essential for expression of type 1 fimbriae in $E$. coli. } \\
\hline & fimB & fimE & fimA & fiml & fimC & $\mathrm{fimH}$ \\
\hline $72(59.0)$ & + & + & + & + & + & + \\
\hline $39(32.0)$ & + & + & - & + & + & + \\
\hline $4(3.3)$ & + & + & - & + & - & + \\
\hline $2(1.6)$ & - & + & - & + & + & + \\
\hline $2(1.6)$ & - & + & + & + & + & + \\
\hline $1(0.8)$ & + & - & - & - & - & + \\
\hline $1(0.8)$ & - & - & + & - & - & + \\
\hline $1(0.8)$ & - & - & - & - & - & + \\
\hline Total 122 & $\begin{array}{l}116 \\
(95.1 \%)\end{array}$ & $\begin{array}{l}119 \\
(97.5 \%)\end{array}$ & $\begin{array}{l}75 \\
(61.5 \%)\end{array}$ & $\begin{array}{l}119 \\
(97.5 \%)\end{array}$ & $\begin{array}{l}115 \\
(94.3 \%)\end{array}$ & $\begin{array}{l}122 \\
(100 \%)\end{array}$ \\
\hline
\end{tabular}

the fims (fragment size of 559-bp containing the fim $A$ promoter) was identified by PCR and subsequently restriction analyzed with HinfI, according to the Nowrouzian and coworkers (2007).

Analysis of gene expression by Real-Time PCR. Total RNA was extracted from cultures with an optical density of $0.6(600 \mathrm{~nm})$ using the SV Total RNA Isolation System (Promega), according to the manufacturer's protocol. The RNA sample was quantitated based on absorption at $260 \mathrm{~nm}$, and purity was determined by the ratio of absorption values at 260 and $280 \mathrm{~nm}$. $2 \mu \mathrm{g}$ of RNA were treated with DNase I (Roche) at a concentration of $1 \mathrm{U} / 1 \mu \mathrm{g}$ of RNA for $60 \mathrm{~min}$. at room temperature. DNase I was inactivated by adding EDTA to a final concentration of $8 \mathrm{mM}$ and heating the samples at $75^{\circ} \mathrm{C}$ for $10 \mathrm{~min}$. cDNA synthesis and real-time PCR

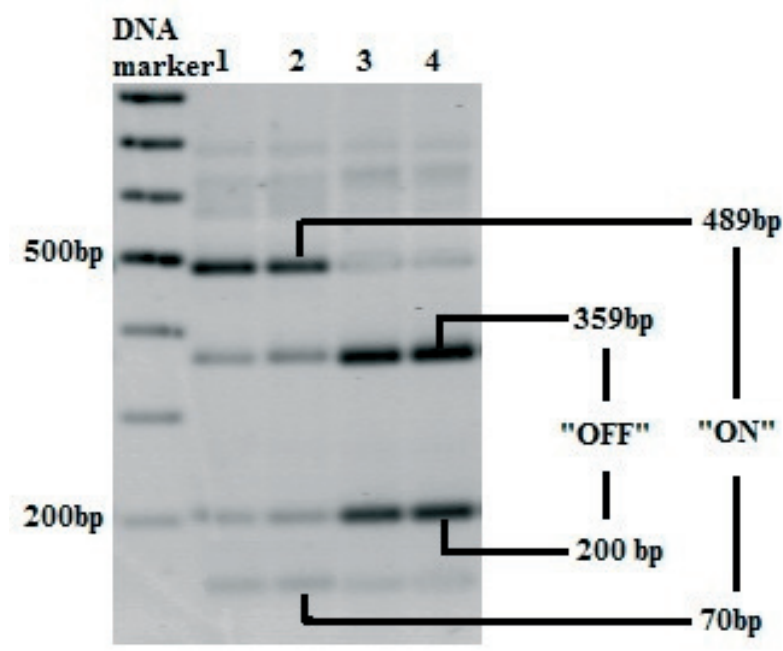

Figure 2. Detection of the switch phase orientation of the fimS promoter of the type 1 fimbriae operon in $E$. coli using PCRRFLP by Hinfl enzyme cleavage.

Cleaved PCR product of strains 1 and 2 indicate the switch phase in the "ON" position while strains 3 and 4 display the "OFF" position. reactions were performed using DyNAmo $^{\text {TM }}$ SYBR $^{\circledR}$ Green 2-Step qRT-PCR Kit (Finnzymes). Reverse transcription was performed in a $20-\mu \mathrm{l}$ reaction mixture containing $0.5 \mu \mathrm{g}$ of RNA, $300 \mathrm{ng}$ of random hexamer primer set, $2 \mathrm{x}$ RT buffer (containing dNTP mix and $10 \mathrm{mM} \mathrm{MgCl}_{2}$ ), M-MuLV RNase $\mathrm{H}+$ reverse transcriptase (containing RNase inhibitor), RNase free water, as described by the manufacturer. The no-reverse transcriptase controls (-RT) were prepared for each DNase-treated RNA sample. cDNA synthesis was performed under the following conditions: primer extension at $25^{\circ} \mathrm{C}$ for $10 \mathrm{~min}, \mathrm{cDNA}$ synthesis at $37^{\circ} \mathrm{C}$ for $30 \mathrm{~min}$, reaction termination at $85^{\circ} \mathrm{C}$ for $5 \mathrm{~min}$ (inactivation of $\mathrm{M}-\mathrm{MuLV}$ ), cooling the sample at $4^{\circ} \mathrm{C}$. Real-time PCR was performed in a $20 \mu \mathrm{l}$ volume containing: $1 \mu \mathrm{l}$ cDNA, $2 \mathrm{x}$ master mix (containing modified hot-start

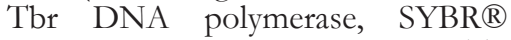
Green I, optimized PCR buffer, $5 \mathrm{mM} \mathrm{MgCl}$, dNTP mix), $400 \mathrm{nM}$ of each primer, and sterilized moleculargrade water, according to the manufacturer's protocol. The sequences of specific primers for each target gene are described in Table 1.

Real-time PCR was performed under the following cycle conditions: denaturation at $95^{\circ} \mathrm{C}$ for $5 \mathrm{~min}$ and 45 cycles of $94^{\circ} \mathrm{C}$ for $10 \mathrm{~s}, 60^{\circ} \mathrm{C}$ (fim $\left.\mathrm{A}\right), 60^{\circ} \mathrm{C}$ (fimB), $61^{\circ} \mathrm{C}$ (fim $\mathrm{C}), 61^{\circ} \mathrm{C}$ (fim E), $60^{\circ} \mathrm{C}(\mathrm{fimH}), 58^{\circ} \mathrm{C}$ (fimI) and $60^{\circ} \mathrm{C}$ (gap A) for $20 \mathrm{~s}$, and $72^{\circ} \mathrm{C}$ for $30 \mathrm{~s}$, followed by a $10-\mathrm{min}$ extension at $72^{\circ} \mathrm{C}$ (Rotor Gene-3000). In each analysis, the negative control probes (no- template control (NTC) and no-reverse transcriptase control (-RT)) were included and no expression profiles (the fluorescence curves) were observed before the onset of 40 cycles of PCR. Positive controls of expression were performed by using primers specific for the gene encoding D-glyceraldehyde-3-phosphate dehydrogenase A (gapA). To ensure specificity of the PCR products, melting curve analysis was performed. Each PCR was performed in duplicate.

\section{RESULTS AND DISCUSSION.}

In fecal samples from healthy people, 127 unique E. coli strains were identified. The whole set of strains was tested for the presence of the fim $\mathrm{H}$ gene which is believed to be a genetic marker for type 1 fimbriae. The fim $H$ gene commonly occurred in the analyzed strains (122/ 96,1\%). Adhesion phenotype of E. coli was tested by haemagglutination assays. The results revealed that all of $122 \mathrm{fimH}^{+}$strains were negative for type 1 fimbriae expression.

Detection of the fim structural subunit genes $(f i m A-f i m H)$ and recombinase fimE and $f i m B$ genes was performed by PCR and revealed the presence of all of the tested genes in 72 strains, but in 50 strains the gene set was incomplete. The absence/deletion of fim $A$ gene $(32 \%)$ was most commonly observed and in other cases $(9 \%)$, the deletion of more than one gene was observed. The detailed results are shown in Table 2.

For 72 strains carrying a complete set of genes, the PCR-RFLP Hinf1 analysis was performed to character- 

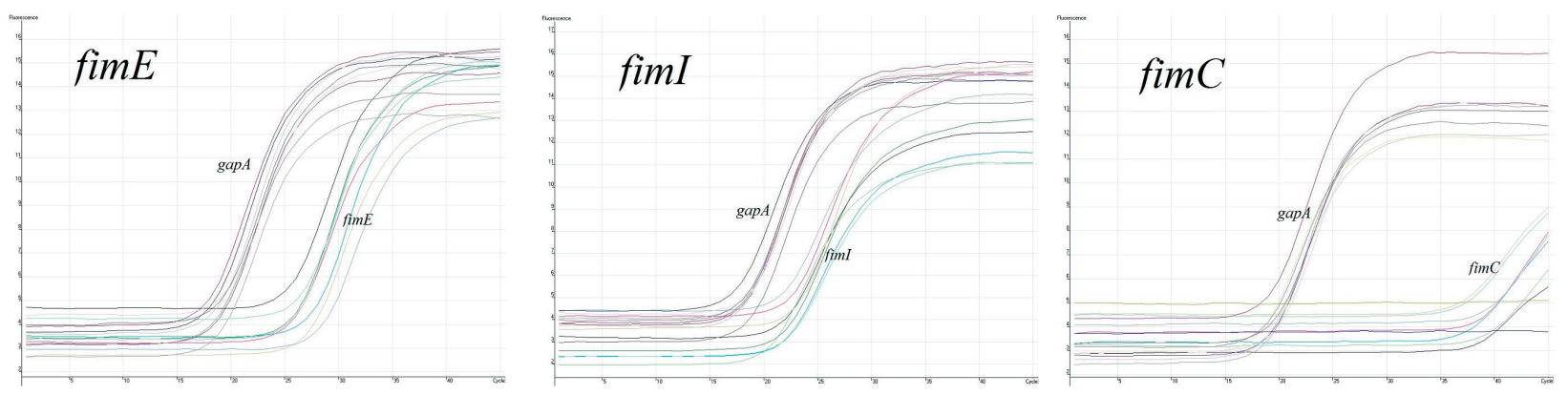

Figure 3. The fim genes expression profile - fluorescence curves of the tested genes and the reference gene - gapA.

Profiles of fimE and fim/ show expression of genes while the profile of fimC shows lack of expression.

ize the switch orientation of the fims promoter region (Fig. 2). In 53 strains the promoter was found to be in the "ON" position (active promoter).

For 53 strains with the active promoter (ON position) the expression analyses of $f i m B$, fimE, fim A, fimI, fim $C$ and fim $H$ genes were performed by real-time PCR. Expression of the fim $C$ gene encoding a chaperone protein and fimH gene encoding adhesin were not observed in any of the tested strains (Fig. 3).

Among 127 commensal E. coli of human origin, $43.3 \%$ of strains had a deletion of at least one of the fim genes responsible for the type 1 fimbriae expression, and $41.7 \%$ revealed lack of expression of the fim $C$ gene. Preliminary research indicated that $85 \%$ of the tested strains did not have ability to expressi type 1 fimbriae, which may suggest that the lack of these fimbriae is an adaptive feature of E. coli to the habitation of the human intestine environment. Further research will explain the lack of fim $C$ gene expression.

\section{Acknowledgement}

This work was supported by the MNiSW grant N N304 176340.

\section{REFERENCES}

Baldy-Chudzik K, Niedbach J, Stosik M (2003) rep-PCR fingerptinting as a tool for the analysis of genomic diversity in Escherichia coli strains isolated from an aqueous/freshwater environment. Cell Mol Biol Lett 8: 793-798.

Blumer C, Kleefeld A, Lehnen D, Heintz M, Dobrindt U, Nagy G, Michaelis K, Emödy L, Polen T, Rachel R, Wendisch VF, Unden G (2005) Regulation of type 1 fimbriae synthesis and biofilm formation by the transcriptional regulator LrhA of Escherichia coli. Microbiology 151: 3287-3298.

Chapman TA, Wu XY, Barchia I, Bettelheim KA, Driesen S, Trott D, Wilson M, Chin JJ (2006) Comparison of virulence gene profiles of Escherichia coli strains isolated from healthy and diarrheic swine. Appl Environ Microbiol 72: 4782-4795.

Ewers C, Li G, Wilking H, Kiessling S, Alt K, Antáo EM, Laturnus C, Diehl I, Glodde S, Homeier T, Böhnke U, Steinrück H, Philipp HC, Wieler LH (2007) Avian pathogenic, uropathogenic, and newborn meningitis-causing Escherichia coli: how closely related are they? Int J Med Microbiol 297: 163-176.

Hernandes RT, Velsko I, Sampaio SC, Elias WP, Robins-Browne RM, Gomes TA, Girón JA (2011) Fimbrial adhesins produced by atypical enteropathogenic Escherichia coli strains. Appl Environ Microbiol 77: 8391-8399.

Iida KI, Mizunoe Y, Wai SN, Yoshida SI (2001) Type 1 fimbriation and its phase switching in diarrheagenic Escherichia coli strains. Clin Diagn Lab Immunol 8: 489-495.

Mitra A, Palaniyandi S, Herren CD, Zhu X, Mukhopadhyay S (2013) Pleiotropic roles of uvrY on biofilm formation, motility and virulence in uropathogenic Escherichia coli CFT073. PLoS One 8: e55492.

Nowrouzian FL, Friman V, Adlerberth I, Wold AE (2007) Reduced phase switch capacity and functional adhesin expression of type 1-fimbriated Escherichia coli from immunoglobulin a-deficient individuals. Infect Immun 75: 932-940.

Schwan WR (2011) Regulation of fim genes in uropathogenic Escherichia coli. World J Clin Infect Dis 1: 17-25. 